\title{
Miranda
}

Revue pluridisciplinaire du monde anglophone /

Multidisciplinary peer-reviewed journal on the English-

speaking world

$8 \mid 2013$

In Umbra Voluptatis : Shades, Shadows, and their

Felicities / Film Adaptations, New Interactions

\section{Sexual Indiscretions, Artistic reflections : Beyond Binaries (Wooster Group's Vieux Carré)}

\section{Xavier Lemoine}

\section{(2) OpenEdition}

\section{Journals}

\section{Electronic version}

URL: http://journals.openedition.org/miranda/5554

DOI: $10.4000 /$ miranda. 5554

ISSN: 2108-6559

\section{Publisher}

Université Toulouse - Jean Jaurès

\section{Electronic reference}

Xavier Lemoine, "Sexual Indiscretions, Artistic reflections : Beyond Binaries (Wooster Group's Vieux Carré)", Miranda [Online], 8 | 2013, Online since 28 June 2013, connection on 16 February 2021. URL http://journals.openedition.org/miranda/5554 ; DOI: https://doi.org/10.4000/miranda.5554

This text was automatically generated on 16 February 2021

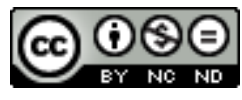

Miranda is licensed under a Creative Commons Attribution-NonCommercial-NoDerivatives 4.0 International License. 


\title{
Sexual Indiscretions, Artistic reflections : Beyond Binaries (Wooster Group's Vieux Carré)
}

\author{
Xavier Lemoine
}

1 The Wooster Group's Vieux Carré faithfully stages one of Tennessee Williams's late plays which made a transient apparition on Broadway in $1977^{1}$. This "memory play" tells the story of a young writer, presumably Tennessee Williams ${ }^{3}$, who struggles with his destiny as an artist and a man. It is an intimate play not only because it is autobiographical, but because it aims at capturing the source of Williams's creativity by returning to his early life experience. By taking us back to a period when he discovered New Orleans in 1939 (Leverich 278-289: 429), Williams explores the decaying and bohemian life in the French Quarter and his budding sexual identity as a young homosexual writer. The Wooster Group's 2009-2011 production ${ }^{4}$, in keeping with Williams's quote : "All good art is an indiscretion" (Williams $2006: 144)^{5}$, can appear as most indiscreet as it peeks into the pants and the fantasies of the main characters. On stage, screens display sexual images, while sounds register the rhythm of desire by intertwining a narrative set in the 1930s with theatrical signs taken from the Warholian world of the 1970s world and from contemporary video artist Ryan Trecartin. The multiplicity of signs complicates the notion of indiscretion as primal drives are turned into words and dialogues into a live concert leading the audience into experiencing an esthetic voyage.

Indiscretion, for Williams, was artistic in the sense that it was a means to reveal truth rather than hiding behind a conventional prudence which often meant silence. In this light, his homosexuality can be a sign of indiscretion as it perturbs the heterosexual norms that had criminalized and pathologized same-sex activities until the 1970s. Williams's theater would, thus, be an attempt to make theatrical trouble and create disorder. Yet, art, as it is based on composition, calls for a certain sense of order. The solution to that contradiction might be that the tensions between "art" and "indiscretion," suggesting a struggle between order and chaos, result in the victory of 
theatrical truth rooted in a binary logic. Indiscretion would, then, be a way to reach visual verisimilitude on stage in a regime of artistic truth. Yet, Williams's play and LeCompte's staging might offer an alternative to this binary structure of representation by using indiscretion as a means of blurring such oppositions. Could it, then, reveal a different meaning of the playwright's script or offer a reassessment of the very basis of Williams's theater? Or does Vieux Carré argue for a revision of the stage that displaces the mechanisms of drama and performance and the status of scopic truth?

By establishing how indiscretions participate in the implementation of a binary logic of representation, we will see more clearly how Vieux Carré touches upon major questions of theatricality. Indeed, the Wooster Group's postmodern staging, by undoing dual impasses, offers a subversive and radical reading of the play.

\section{Sexual Indiscretions: the Rules of Order and Disorder}

Williams's plays are clearly personal, exploring the human psyche by displaying it to the public eye. In that light, the tensions between the public and the private articulate the notion of indiscretion on stage. This opposition has been constant throughout his work, most famously with A Streetcar Named Desire which, in its 1947 original staging, used screens and lighting to turn the interior of the apartment into exterior street scenes, reflecting the opening stage directions (Kolin 13-14) ${ }^{6}$. In order to evoke indiscretion, the author must build a frame that sets up the binary opposition discretion/indiscretion that will enable the audience to peek into the world of the play and discover what is not supposed to be made public. The frame relies on the articulation of a series of binary oppositions-public/private, visible/invisible, homosexuality/heterosexuality-which points at the dual logic defining this fictional world. The sense of revelation, however, is not merely fictional since it is intricately connected to Williams's life. Vieux Carré, can be considered doubly indiscreet because it reveals Williams's biography and exposes the "true" source of his artistic inspirations by plunging the audience into the maelstrom of his sexual desire and his quest for creativity.

In the plot, the discretion/indiscretion binary is made visible thanks to the unruly life of the French Quarter. Indiscretion gives us access to a world of chaos symbolized by poverty, madness, and insatiable desire which keep piercing through the surface of conventions. Chaos might be the first impression conveyed by the Wooster Group's stage which is littered with used objects, including old pillows, books, pans, radio etc. As a result, the main playing areas, especially a large platform slightly raised above the stage that generally stands for the cubicles where the roomers sleep, gets messier and messier as the play unfolds. This is, however, a carefully constructed disorder that Le Compte rigorously gauges ${ }^{7}$ so that it remains readable by the audience as trash and does not become a shapeless and meaningless heap. In other words, it elaborates an aesthetic of trash echoing Williams's quest for a new aesthetic order struggling against established conventions and the underground style of 1960 s and 1970s-as best illustrated by Jack Smith's work ${ }^{8}$.

6 At a surface level, order in Vieux Carré defines a sense of discretion based on the enforcement of the normative rules upholding conservative values. So the disruptive aesthetic of trash is set against bourgeois social rules. The landlady, Mrs Wire performed by Kate Valk, controls the comings and goings of her roomers as she wants 
them to follow her rules including not coming in late, not making noise, not bringing in strangers etc. She asserts : "I'm keeping watch on the comings and goings at night of tenants in my house." (Williams 1992: 11) Proper sexual behavior appears to be her main concern as she is especially worried about the entrances at "night" and reproaches Jane and Nightingale with their sexual partners introduced in her house. While she tolerates Jane's male lover, she manages to scare away Nightingale's pickup. She marks, nonetheless, any relations outside of marriage as transgressive. The representation of sexual transgression, then, allows for the conceptual space of the discretion/indiscretion binary to exist. The mimetic game between the main screen on stage, fully visible to the audience, and the live actor who performs the pick-up indicates a reflection on the classical theatrical rule of imitation. Indeed, on the screen the audience sees an excerpt of Morrissey's film Trash with a young man who looks like Nightingale's pickup (mainly through his attitudes and clothes).The staging then toys with the notion of representation as founded on an imitation of nature, which upholds the binary logic in the area of representation-even though here nature is in fact a film.

The dualist interpretation is also maintained by the other tenants who each in their own ways relay and repeat the norms. Jane Sparks wants to tame her wild boyfriend Tye McCool as the onomastics playfully evokes the hot/cold opposition which is also duplicated on stage with the small TV set on the floor which regularly broadcasts images of water and fire. Similarly, the Writer desperately attempts to respect conventions by being too honest. As a result, they all collaborate to enforce social order and even more so a moral order that permeates their view of the world. Mrs Wire asserts : "society folk in this city may tolerate vice but not me." (Williams 1992:55) and further "the Vieux Carré is the new Babylon destroyed by evil in Scriptures!" (59). The references to vice and sin opposed to virtue and saintliness feed into the basic value system created by a binary moral system. Furthermore, she is trapped in a mythical past which makes her misread the present. But how is this working in the play beyond discourses? How do we get to see through the system so that we realize it is there?

As we saw, Mrs Wire stands for a regulating principle through the repetition of her inquisitive and authoritative "Who? Who?" (7, 9, 20, 35). This is amplified by Nightingale's parody clearly rendered by Scott Shepard's delivery of these lines :

Nightingale: When I came in she sprang up and hollered out, 'Who?' And I answered her with a hoot owl imitation, 'Hoo, Hooo, Hooooo.' Why, the lady is all three furies in one. (20)

The question becomes a savage cry, a primal scream exposing the basic function of such a monitoring: to control fear by imposing the law. Mrs Wire is a grotesque (Cohn 235) figuration of the law that keeps failing, or rather of the norms, and especially here, past social norms that are clashing against actual acts. This explains the reversal that turns her normative character into a crazy woman. She is referred to several times as a mad "witch" (Williams 1992: 12, 48, 71, 87) failing to follow the order she would like to enforce. Similarly, all her roomers are breaking her rules to the point where she herself becomes literally the abuser of the law when she is tried by a judge who condemns her for pouring burning water on one of her new tenants. What triggered her own conduct of (mental) disorder was a party taking place, scene seven, in the basement of her house. This party, thrown by a fashionable and connected New Orleans gay photographer, is described as "orgies" (55) by Mrs Wire as she desperately wants to repress sexual desires because they threaten the neat binary distinctions that are necessary to uphold her moral system. Despite this reversal, we are still within an 
indiscretion/discretion tension fed by the same general rule now privileging madness. The arrest and trial of Mrs Wire takes place offstage while on the main screen center stage "The Trial" section from the film The Wall displays the face of a judge portrayed as giant buttocks. This could illustrate Mrs Wire's lunacy and the whole madness of the legal system. This animated caricature of the law, anchored in the genitalia, makes sexual indiscretion a way to reveal the deeply corrupted human nature. It further relies on the way the Wooster Group discreetly intertwines personal indiscretions, as the choice of Pink Floyd's album was the idea of one of the main actors, and the script so as to create live performance. In a sense, the whole staging results from a montage that elaborates on personal experiences, private tastes, visions, imaginations of the Wooster Group's members. Their style is defined by those discreet indiscretions interlaced with Williams's own.

Sexuality is a clear measure of the binary force of indiscretion to the extent that it is socially constructed as something that must be kept out of sight-and as such triggers the desire to see it. This does not contradict the project of realism ${ }^{9}$. On the contrary, what could illustrate better than the "fourth wall," a canonical ingredient of realism, this idea of indiscretion as the public is invited to look inside the (bourgeois) home and relish in voyeuristic pleasure? This might explain why Williams was so successful on Broadway when he toyed with sexual tensions exposing dirty little secrets in elaborate style. His art of indiscretion could have merely been a perfected version of theatrical visibility as defined by the Broadway conventions and the social norms of the 1950 s. Repressed sexuality reluctantly revealed, in line with Foucault's "repressive hypothesis", was the favorite illusion of the times. Yet, when Vieux Carré was produced on Broadway things had changed and it was harder to grasp the type of indiscretions Williams exposed. Was it homosexuality? In a sense, this indiscretion is not new but just more visible than say in A Streetcar Named Desire, Cat on a Hot Tin Roof or even Suddenly Last Summer. Whereas in those plays homosexuality is framed as a secret that brings on some kind of revelation of truth (primordial or secondary), in Vieux Carré the Writer's homosexuality is tackled almost from the start (scene two) in a rather direct manner. The tale of his sexual awakening is still constructed as an indiscretion articulated on a sense of discretion that excludes sexuality from disclosure. The Writer immediately forswears his confession: "I didn't mean to tell you all that" (Williams $1992: 25)$ thereby sealing the binary structure. The private should not be told but needs to be told to be private. As Savran has suggested in his analysis of In the Bar of a Tokyo Hotel (1969), the 1970s is a period when Williams tried a new style based on indirection as he had come out in a period when homosexuality was not so secretive (Savran 1992 : 131-144). However, the narration of sexuality remains elliptic in Williams's script be it Nightingale's seduction of the Writer or Jane's tragic sexual dependency on Tye. That's why the evocation of sexuality remains based on a model of indiscretion albeit a fully conscious one. The centrality of sexuality is not canceled out but weakened, eroding the binary logic and making it less essential.

11 The Writer's shyness (Williams 1992: 30) and his silences suggest that he frames the notion of discretion but also the whole structure of the play as he is also a narrator who opens the play by indicating that we are witnessing his "recollection" and entering his "memory" (5). On the contrary, Nightingale keeps chattering and making sexual overtures and as such could serve as the ruler for indiscretion combining verbal, sexual 
and visual disorder. Williams clearly emphasizes this opposition when they first meet in scene two :

Nightingale : (...) Like many writers, I know you are a writer, you're a young man of very few spoken words, compared to my garrulity.

Writer: Yes, I

Nightingale: So far, kid, you're practically... monosyllabic. (17) discontinuous scenes that introduce the Writer's fantasies. The Wooster Group fills in the script's ellipses with a number of private images. They visualize the Writer's homosexual fantasies by displaying on the main screen located center stage pornographic films. Interestingly so, the black and white film is a rare version of a pornographic film featuring Warhol's star Joe Dallessandro who is at the center of Paul Morrissey's Flesh (1968), Trash (1970), Heat (1972) ${ }^{10}$. This is the result of an elaborate system mixing live and recorded images. In scenes two and four a camera films Fliakos's gestures which are fused with prerecorded images of men having sex creating sexual images (blow jobs, caresses) involving the Writer. While Fliakos faces the screen, his back to the audience, the main screen reflects his carnal desires but also transforms them as he seems to follow the movements of the actors on the screen. The intrusion of pornographic images on stage raises the question of the audience's potential pleasure/ displeasure in indiscretion. The mingling of live flesh and celluloid skin partially relies on a divided perception. Yet, it could be considered as a break in the conventions of representation to the extent that in mainstream theater pornography is excluded. It would mean the intrusion of one mode of representation (pornography) into another (theater) which could serve as a figuration of artistic indiscretion. The indiscretion, then, would be rooted in the fact that the public's eyes penetrate a private sphere thus upholding such a distinction. In turn, this movement is articulated through the interlocking media where the live and the recorded, the screen and the stage all maintain their integrity, their identity. Yet, the distinctions tend to dissolve in the performance only remaining as a trace of a decaying register of reception.

So does indiscretion truly make it good art? Does it mean that good art must be ruled by the binary logic of the revelation of the hidden? By helping us see the Writer's fantasies through sexual images, do we experience an aesthetic pleasure? Are we exposed to new forms and ideas? (If such criteria can be considered to determine what 
art is-and a good one at that!) The answer to those questions will always remain subjective but two brief answers come to mind. First, yes the binary logic allows constructing a series of ideas and figures that help shape the real and the imagined. It could be objected, however, that such logic only reproduces the norms and conventions that indiscretions were supposed to upset. A binary frame would reinforce clichés rather than question them and this would be contradictory to the demands of "good art." A second answer then requires searching how the indiscretions staged by Williams and the Wooster Group can explore new aesthetic configurations and ideas in a way that does not merely maintain ontological categories. By mixing media, styles and yet achieving a performance it suggests that the binary frame is not enough to account for the Wooster Group's appropriation of Vieux Carré.

\section{Beyond the Binary Logics of the (Mis)Representation of Indiscretions}

17 The repetition of a binary logic through the notion of discretion/indiscretion is readily disputed by the Wooster Group's version of Vieux Carré. The constant collapse of simplistic oppositions undermines a strict belief in the validity of the binary rule even if we have argued in the first part that they can offer more complex figures as well. The abundance of theatrical signs, typical of the Wooster's work, ensures that it is impossible to believe in an uncomplicated visibility merely defined by its alleged opposite. What appears on stage is a series of layers only partially accessible. In a sense, we can argue here for a partial perception based on an opaque indiscretion. Indiscretions are not merely constructed through the exclusion of discretions nor are they interwoven, as shown in the first part, but that they keep failing to cohere into one single/full meaning. Their binary perception becomes incomplete or transformative.

18 The amount of references defining the visual and aural quality of the performance can be identified but none can be considered as a "master key" (Williams $1992: 74)$ to open the closed doors of interpretation. In scene eight, the locked doors of the script requiring a master key are demanded by Mrs Wire. But what is visible on stage is an upstage door which does not hide Nightingale who is center stage on the main performing area. So there is no sense of disclosure on this dying man but rather a full view on his Quixotic struggle against Mrs Wire's obtuse realistic medical diagnosis of his disease (hence her recourse to medical authority which will ironically turn against Mrs Wire when Nursie appears in a white hospital outfit at the end of the play). Nightingale's grabbing his easel to the rhythm of cymbals, evocative of a Chinese opera briefly visible on monitors designed for the actors to see, confirms the need to open up the readings of that confrontation between two characters. The audience is involved in a refusal to surrender to realistic interpretations by summoning up various points of view on art. The easel becomes Nigthingale's weapon and the pleasure of exploring Asian acting styles his resistance. The numerous references can be freely combined by the spectator so that they fully participate in the here and now of the performance (although some people can feel lost and frustrated instead of engaged and actively participating to the performance). This is not incidental but it commends the whole staging as the most recurrent footages, taken from the Morrissey's trilogy and Trecartin's art videos, displayed on the actor's monitors suggest. Trash, Flesh and Heat 
open up multiple readings in connection with the 1970s New York avant-garde world and Williams's real life when he rejoiced hanging out with the Warhol crowd and Candy Darling ${ }^{11}$. This interpolation of "real" life, various chronological lines and artistic worlds prevents the audience from a univocal interpretation and undo the binary grids. Similarly, the images from contemporary video artist Ryan Trecartin offer another line that cuts across the esthetic of the 1970s which was visible through the actor's costumes like Tye's bandana reminiscent of Dallesandro's. The various time references also introduce the Wooster Group's own history which started in 1975 and has been dedicated to creating its own artistic gestures weaving biographic and esthetic indiscretions in the secrecy of unstable interpretations (Savran $1986: 65$ ).

Williams's script is amenable to such a staging as it defies a reading that would be based on a one shot revelation even if the stage directions might sometimes privilege a nostalgic vision where indiscretion rules while the dialogues remain more discreet. Such dichotomy is only partial as the Writer's lines are often interrupted, fragmented, and incomplete while the stage directions compete with the Writer as narrator to engineer an atmosphere studded with mute images. As a result, the play tends to be an open ended quest rather than a world of definite revelations. The reversals inscribed in the plot suggest as much to the extent that they keep questioning perceptions and interpretations. The Shakespearian reversal of time when Mrs Wire cooks at midnight instead of noon erodes Mrs Wire's normative role at the beginning of scene four and illustrates the instability of signs which thwarts the binary stabilization of meaning beyond a mere reversal of polarity. This inversion of day into night does not only mirror Mrs Wire's failure to enforce the norm, as we suggested earlier, but allows for poetic compositions mixing Macbeth's eerie witches (Williams 1992: 35), the lascivious landlady of the motel in Heat who appears on the actor's monitors, and the transgender Holly Woodland who inspired Walk's interpretation of Mrs Wire. The general feeling is that indiscretions inform the avant-garde and the classics through the fusion of performance to become a fantasy world. Drugs distort perceptions further as the vaporous underworld of Trash mixes with Tye's reefers and needles overshadowed by Williams's own Seconal and alcohol abuse. Drugs, at best, provide a sense of sensory exploration, stimulating imagination and permeating the atmosphere of the play: an artificial indiscretion.

If drugs might remove some mental barriers, the Group's effort is to create a free space, here signified by the open stage allowing the actors to enter and exit beyond the logic of the realistic door. The house's alleged fourth wall is on all sides and repeatedly displaced-to the point of disintegration. Doors are sliding (sometimes underlined by an amplified sound of sliding door), actors come on stage from left and right, the video artists are downstage in full view while the sound table and artists sit in the back of the house. The false window panes, appearing on the three main screens, crack with real noise of glass breaking. In the performances where this effect was added the actress does not bleed, as is the case in the script, disregarding verisimilitude and preferring playing with the transparency metaphor. LeCompte underlined this when she picked those effects (in a rehearsal I attended in Dijon) looking for something that was not too literal or logical. This rejection of realistic conventions as organized through the principle of discretion about the illusion of theater (a copy of reality based on the origin/copy model) is clear from the start in Williams's script : "a realistic setting is impossible, and the solution lies mainly in very skillful lighting and minimal furnishing" (Williams 1992: 4). Then, the set of the performance is made up of a 
fragmented space crisscrossed by a series of parallel and diagonal lines created by cables and doors on railings. This classic avant-garde move to resist the copy of Broadway settings has long freed the Group from conventional acting and staging. As Carson (Carson 172) and others have noticed, this abstract theatricality also borrows from non-Western styles including the traditional Japanese Noh Theater with direct quotations through music, videos and gestures mixing also with Chinese Opera in Vieux Carré. Transparency can no longer be upheld as a simple vehicle unbeknownst to itself.

Indeed, visibility is troubled by an accumulation of sensory stimulations. The central role of sound contributes to a feeling of random accumulations made up of brief and loud sounds, accelerations of rhythms, loops, mixings of unusual sounds (peacock, also in the script), and reverberations. An almost constant soundbed scrambles, in varying degrees, the dialogues adding to the confusion of lines that are sometimes sped up to the point of incomprehension. This can create the feeling that the audience is eavesdropping on the performance, stirring the desire to be indiscreet so as to grasp the meaning of the words and the images that are circulated on the stage. To put it differently, this tumult stimulates the wish to hear and see things that tend to escape perception, almost to the point of frustration to the extent that this vision and sound is simultaneously granted and denied. This type of reception might only be the measure of the inadequacy to understand indiscretion through a binary logic. In that sense, the Wooster's staging forces a self-reflection on the audience's drive to be indiscreet but also to see art in general.

The Wooster Group, then, highlights a reflexive process on the writing / staging of theater delving into the most private parts of Williams' life as he asserts in his Memoirs : "And my habits of work are so much more private than my daily and nightly existence." (Williams $2006: 154)$ This growing role of writing in the play is symbolized by the small table that is installed downstage center and from where the Writer can record the people's interactions in the rooming house. Fliakos, like a poetic machine, types more and more feverishly echoing Williams's own self-reflection:

Maybe I am a machine, a typist. A compulsive typist and a compulsive writer. But that's my life, and what is in these memoirs is mostly the barest periphery of that which is my intense life, for my intense life is my work." (Williams 2006: 84)

Accordingly, sexual fantasies give way to jumbled letters which are displayed across the screens. Although the dialogues remain mostly understandable, what is striking is that we get to see how the writer created them as Fliakos repeats some phrases or says them before they are spoken by the characters. He becomes a conductor who embodies all the characters as he, literally, eavesdrops on the fight between Jane and Tye. The Writer proudly claims : "writers are shameless spies." (Williams 1992: 95) but the focus is not so much on what is being revealed by the indiscretion as on the energy involved in the recording of it. Fliakos intense acting focuses on the rhythm rather than on a specific message. The letters flashing on a section of the central screen do not indicate so much that there is no meaning but that what matters is the drive to record life through the alphabet and, at the same time, the enigmatic disjunction between the two. It points at the process of indiscretion through discrete discretions. This is not just a coincidental articulation with the Wooster Group's work but is highly characteristic of the overall structure of this piece. Indeed, LeCompte practices a discreet direction thanks to the in-ear receiver ${ }^{12}$ through which she talks to actors during the performance as a conductor of an orchestra (not unlike the Writer's figure). This adds a discreet level to the performance, a secret live direction for the actors. So their acting 
is under the influence of various sound bits replete with revelations and secrets. What matters most perhaps are the live traces left by all those stimulants and the potential they provide to reflect or deflect life on stage. The play, then, points at a series of levels, of windows opening up onto another series of references and what is retained is not the specific meaning that would yield a revelation and truth but the very process of proliferation that makes it impossible to rely on an absolute truth and underscores the competing discourses that claim to be the truth. But it is in the motifs of the contradictory dialogues and clashing images that there is a potential to seize this specific meaning of indiscretion. This idea is reflected in another definition of good art by Williams given in a later interview :

WILLIAMS : Oh yes. All good art is essentially revolutionary, in the wide sense of revolutionary. 'Revolutionary' is a misunderstood word.

WHITMORE : I'm trying to get a little more specific. If we're going to have a gay community that has a revolutionary thrust to it, should we be concentrating on agit-prop theater-or propagandistic or street theater?

WILLIAMS : Well that is never art really, if it's strictly that. It has to be implicit; revolution is implicit; not explicit, but woven into the fabric of the work. (Whitemore 316)

24 This idea that all good art has a general pattern ("fabric") is significant and underlines the notion that indiscretion, like revolution, must be woven in the structure of the work. Here, the idea that art is implicitly revolutionary qualifies indiscretion by confirming that indiscretion is about undoing the norms through subversion. That is to say that this revolution takes place within the constraints of the art of representation by reassessing the rules that codify artistic production and reception.

The Wooster Group's postmodern staging of Vieux Carré performs such subversion by playing up the potential destabilizing force of the text and renewing Williams's idea of indiscretion today. Isn't that Williams was after, as Bigsby reminds us, “(...) a plastic theatre, fluid, evanescent, undefined and undefining." (Bigsby 40) Through and beyond sexual indiscretions, Vieux Carré and the Wooster Group's version are about conjuring up this feeling of troubled perception. Thus postmodern indiscretion is plural resulting from frontal homosexual pornography as well as oblique evocations of loneliness, loss and death. The play especially creates oxymoronic situations suggesting a blind indiscretion. Veiled vision from the blind bats of the opening scene to Jane's blurred sight (Williams 1992:112) is reflecting on this faulty perception. The classic theme of mirror echoes this especially as false reflections and fake transparencies abound in the production. This is almost a tradition for the Wooster Group of course as Kate Walk explained in an interview: "we use the monitors as mirrors, or as sources of information that either illustrate what we're doing or disrupt what we're doing." (Rosten 456) In the last scene, Tye dresses up carefully looking at himself in a mirror which is in fact a screen with a film of himself dressing up, which then he imitates live on stage as if it were his true reflection. It becomes hard to unravel the live from the recorded and even more to know for sure who can claim the truth of representation. This interrogation is furthered with false transparencies when the screens show images of the counter-weight sandbags which are in fact located behind the screenssuggesting that what frames the play is both real and illusory. These games of visual echoes seem to reflect on the spectator's gaze and the construction of perception. Indiscretion could work here by simulating sight questioning thus the very organ of vision and its reliability. At the very least, this raw theatrical resource is continually 
disputed by the script and the staging. The Writer's cataract, echoing Williams's own cataract, highlights the significance of veiled eye-sight-traditionally the way to visions. The Writer admits to "eye trouble" (Williams 1992: 36) alluding to the classic pun leading to a more abstract identity problem ("I" problem) and the basis for introspection. Almost like a Hawthornian revelation in penumbra, the Writer accessed to more self-knowledge when "everything visible was gone" (Williams 1992:26) as he sees a ghost or an angel (the angel of the title of the short story: "The Angel in the Alcove") figured on the three main screens by a mere shadow passing through window frames-an image that recurs throughout the staging and the script (Williams 1992:93, 107). Uncertainty is at its height as the text signals : "An almost invisible gesture of... forgiveness ? ... through understanding ? ... before she dissolved into sleep..." (27). The breaks, the question marks, the evanescent perception appear enmeshed with the dancing, glistening specks on Fliakos's body evoking a pool of light and water. Oxymoronic sensory experiences conveyed by the sound and sight of rain suggest a liminal substance between life and death, pleasure and pain, visibility and invisibility. The binary harness dissolves in this theatrical wet dream whose magic is conjured up by the interlocking of script, acting, and technology. Maybe the play is all about grasping a sense of in-betweeness as the writer towards the end addresses the audience and explains: "I stood by the door uncertainly for a moment or two" (Williams 1992 : 116). Williams's Vieux Carré captures a spatial and temporal in-betweeness on the brink of life and art which the Wooster Group magnified through a performance that derails the indiscretion/discretion binary debunking the rules and regulations of representation and offering an exultant and live exploration of the contemporary American stage.

\section{Conclusion}

Indiscretion can be seen as figure that translates both Williams's and the Wooster Group's work on Vieux Carré. If it might first appear as a mere binary figure that perpetuates a restrictive tradition of representation, I hope to have suggested that it is much more than that. Indiscretion is not merely a trick to reveal truth but also a means to bring about a subtle revolution in forms and ideas on stage. By multiplying the frames of references that determine the conditions of an indiscretion, the Wooster Group managed to capture Williams's subversive potential which would qualify the artistic function beyond binary terms. The live fabrication of the performance highlighted by task-based acting rather than psychological identification resists the fantasy of clear sightedness and emphasizes the half clear, half cloudy (to borrow freely from Williams' title Something Cloudy, Something Clear) status of the artist, just like the one-eyed Writer. This dual position, however, does not repeat a binary theater but, through its multilevel practice, offers a version of contemporary deconstruction in American performance. Performance, then, can reclaim the opaque, the obscure and the unstable as fully participating in the elaboration of an artistic gesture that must be reinvested in the present to keep the power of artistic indiscretion alive. After all, it must be remembered that Williams's phrase was a strategy to resist against attacks of his art, as he explained in his Memoirs : "People have said and said that my work is too personal : and I have just as persistently countered this charge with my assertion that all true work of an artist must be personal, whether directly or obliquely, it must and it does reflect the emotional climate of its creator." (Williams 2006 : 188) The Wooster 
Group's Vieux Carré designed their own response by performing a postmodern indiscretion to deploy a strategy that resists the foreclosure of binary forces ceaselessly threatening the artistic gesture.

\section{BIBLIOGRAPHY}

Bigsby, C.W. E. Modern American Drama, 1945-1990. New York : Cambridge University Press, 1992. Bloom, Harold. "Introduction" In Tennessee Williams. Updated Edition. Ed. Harold Bloom. New York : Infobase Publishing, 2007. 1-10.

Bray, Robert. "Vieux Carré : Transferring 'A Story of Mood'." In The Undiscovered Country: The Later Plays of Tennessee Williams. Ed. Philip C. Kolin. New York : Peter Lang, 2002. 142-154.

Brecht, Stefan. Queer Theatre, Frankfurt : Suhrkamp, 1978.

Carson, Marvin. The Haunted Stage : The Theatre as Memory Machine. Ann Arbor : University of Michigan, 2001.

Cohn, Ruby. "Tennessee Williams : the last two decades." In The Cambridge Companion to Tennessee Williams. Ed. Matthew C. Roudané. Cambridge : Cambridge University Press, 1997. 232-244.

Callens, Johann. (ed.) The Wooster Group and Its Traditions. Brussels, Belgium : P.I.E. -Peter Lang, 2004.

Foucault, Michel. Histoire de la sexualité : I la volonté de savoir. Paris : Gallimard, 1976.

Jenkins, Cindy Marie. "The Wooster Group Enhances Memory at REDCAT." LA Stage Time. 1 December 2010. December 16, 2010. <http://www.lastagetimes.com/2010/12/the-wooster-groupenhances-memory-at-redcat/>

Kolin, Philip C. Williams, A Streetcar Named Desire. Cambridge, UK : Cambridge University Press Cambridge, 2000.

LeCompte, Elizabeth. “Une 'pièce de mémoire,' Entretien avec Elisabeth LeCompte.” Interviewed by Denise Luccioni. The Wooster Group, Vieux Carré de Tennessee Williams. Paris program : Centre Pompidou, 19-23 novembre 2009, Festival d'Automne, 38ème édition. 3-5.

Lemoine, Xavier. "Spirales baroques : quand le Wooster Group tourne et retourne Hamlet." In Théâtre Anglophone. De Shakespeare à Sarah Kane : l'envers du décor. Eds. Claude Coulon, Florence March. Montpellier : L'Entretemps, 2008. 61-73.

Pettrow, Daniel. Unpublished email interview, received on Sunday December 19, 2010.

Quick, Andrew. The Wooster Group Work Book. New York/London : Routledge, 2007.

Rosten, Bevya. "The Gesture of Illogic : An Interview with Kate Walk by Bevya Rosten." February 1998 in The American Theatre Reader : Essays and Conversations From American Theatre Magazine. New York : Theatre Communications Group, 2009. 455-458.

Savran, David. Communists, Cowboys, and Queers : The Politics of Masculinity in the Work of Arthur Miller and Tennessee Williams. Minneapolis, London : University of Minnesota Press, 1992. 
---. Breaking the Rules : The Wooster Group. New York : Theatre Communications Group, 1986.

Saddik, Annette. "Critical Expectations and Assumptions : Williams' Later Reputation and the American Reception of Avant-Garde.” 1999. In Tennessee Williams. Updated Edition. Ed. Harold Bloom. New York : Infobase Publishing, 2007. 123-141.

Stokes, Emily. "Kate Valk's devotion to the stage." Financial Times.com, 30 October 2009. Accessed November 29, 2009. <http://www.ft.com/cms/s/2/7a6d3ea6-

c4e3-11de-8d54-00144feab49a.html\#axzz1PMSnIJOw>

Whitmore, George. "George Whitmore interviews TENNESSEE WILLIAMS.” In Gay Sunshine Interviews, Volume 1. 1978. Ed. Winston Leyland. San Francisco : Gay Sunshine Press, 1984. 309-325.

Williams, Tennessee. Memoirs. 1972/1975. New York : New Directions, 2006.

---.Vieux Carré. In The Theatre of Tennessee Williams, Volume VIII, New York : A New Directions Book, 1992. 1-116.

---.The Theatre of Tennessee Williams : In the Bar of Tokyo Hotel and Other Plays, Volume 7, New York : New Directions, 1981/1994.

---. Cat on a Hot Tin Roof and Other Plays. London : Penguins Books, 1976.

---." The Angel in the Alcove." 1948. In Tennessee Williams, Collected Stories, New York : Ballantine Books, 1986. 125-132.

\section{NOTES}

1. The play had its previews at the St. James Theatre for 11 performances starting 30 April 1977. It then opened and ran from May 11 to May 15 1977. Accessed 22 November $2010<$ http://www.ibdb.com/production.php?id=4001>

2. The opening lines of the play are stating this plainly, connecting this play to The Glass Menagerie: "In my recollection it [house] still is but by shadowy occupants like ghosts. Now they enter the lighter areas of my memory." (Williams 1992: 5)

3. As Williams claims in "The setting of the play": "the writer (myself those many years ago)" (Williams: 1992, 4)

4. The play was performed at the following venues: National Theatre of Strasbourg, 6-14 November 2009; Centre Pompidou, Festival d'Automne, 19-23 November 2009; Edinburgh International Festival, 21-24 August 2009; Redcat, Los Angeles, 1-12 December 2010, New York February 2-27, 2011; De Singel, Antwerp 4-7 May 2011; Théâtre Dijon Bourgogne, 18-21 May 2011, Holland Festival, Amsterdam 11-13 June 2011 and back in France at TNT, Toulouse, 22-26 November 2011.

5. This is a recurrent theme in Williams's essays. See for instance his note "Person-ToPerson" (Williams 1976: 7-10) as an early development of this notion under the term of "personal lyricism." We can notice that this introduction to Cat on a Hot Tin Roof was less assertive about the link between art and indiscretions as he lamented the necessary connection he saw between "creative work" and "personality."

6. "Light from the front of the stage signaled the interior while light from behind the gauze scrim revealed exterior scenes, or the 'desolate street outside' (Wolcott Gibbs) as when Blanche is led off to the madhouse or Stanley eavesdrops on the sisters' conversation in Scene Four." (Kolin 13-14) 
7. I could witness this when observing rehearsals in Dijon in May 2011.

8. See, for instance, "Jack Smith, 1961-71. The Sheer beauty of junk." (Brecht 10-27)

9. See: "Fugacity: Some Thoughts towards a New Naturalism in Recent Performance," Simon Jones (Callens, 152-4).

10. Discussion with Ari Fliakos, Andrew Schneider and Daniel Pettrow, Toulouse, TNT, 24 November 2011.

11. He wrote in his Memoirs: "I like the crowd I'm with, here in Venice, all of them: Sylvia Miles, Joe Dallessandro, Paul Morrissey, little Andy Warhol so much like a lost little boy, lost in time. Morrissey strikes me as someone very special. I would like him to make a film of one of my short stories: why not 'Two on a Party,' which maybe the best of the lot?" (Williams 2006: 216-7) and his mention of Candy Darling (Williams 2006: 35) who performed with Williams in Small Craft Warning in 1972 as Violeta.

12. Many thanks to Andrew Quick for pointing this out to me.

\section{ABSTRACTS}

The contemporary American performance group, the Wooster Group, seems to have staged Tennessee Williams's Vieux Carré in keeping with the playwright's idea that "All good art is an indiscretion." The tension between "art" and "indiscretion" suggests a struggle between order and chaos based on a binary regime of representation resulting in the victory of truth. Sexual indiscretions appear to be a key element as on stage screens display gay pornographic images while sounds register the rhythm of desire by mixing the script, based in the 1930s, and theatrical signs from the 1970s and 2000s. Yet, Williams's play and LeCompte's staging offer a reassessment of such binary logic of representation. They create the possibility of productive postmodern indiscretions yielding the subversion of theatrical codes. An opaque indiscretion explores the complex articulations of performance operating on multiple levels and capturing the evanescence of art.

La mise en scène de Vieux Carré de Tennessee Williams par le Wooster Group, une troupe américaine contemporaine, semble avoir suivi à la lettre l'idée du dramaturge pour qui : "Une œuvre d'art réussie est une œuvre d'art indiscrète." La tension entre "art" et "indiscrétion" évoque l'opposition entre l'ordre et le chaos qui fonde le régime binaire de la représentation scellée par le triomphe du régime de vérité. Les indiscrétions sexuelles semblent être un élément clef illustré sur scène par des écrans qui montrent des images pornographiques gay tandis que l'univers sonore capte le rythme du désir en tissant le script de la pièce, qui se déroule dans les années 1930, avec des signes théâtraux inspirés par les années 1970 et 2000 . Toutefois, la pièce de Williams et la mise en scène de LeCompte remettent en question cette logique binaire de la représentation. Ils mettent en place les moyens de créer les conditions de possibilité pour que les indiscrétions postmodernes soient fertiles et puissent subvertir les codes de la scène. Une indiscrétion opaque permet alors d'explorer les articulations complexes opérant à de multiples niveaux afin de saisir l'évanescence de l'art. 
INDEX

Mots-clés: théâtre américain, Wooster Group, postmodernisme, représentation, multimédia, homosexualité, performance

Keywords: US theater, Wooster Group, postmodern, representation, multimedia, homosexuality, performance

\section{AUTHORS}

\section{XAVIER LEMOINE}

Université de Nantes

Maître de conférences

xavier.lemoine@univ-nantes.fr 